\title{
Exploring Factors Influencing Continuous Viewing Intention of Chinese Documentary Programs among Undergraduates
}

\author{
Mengyu Li, Megat Al Imran Yasin, Norliana Binti Hashim, Lay Hoon Ang, \\ Hongzhe Kang
}

To Link this Article: http://dx.doi.org/10.6007/IJARBSS/v11-i3/8960

DOI:10.6007/IJARBSS/v11-i3/8960

Received: 01 February 2021, Revised: 27 February 2021, Accepted: 07 March 2021

Published Online: 16 March 2021

In-Text Citation: (Li et al., 2021)

To Cite this Article: Li, M., Yasin, M. A. I., Hashim, N. B., Ang, L. H., \& Kang, H. (2021). Exploring Factors Influencing Continuous Viewing Intention of Chinese Documentary Programs among Undergraduates. International Journal of Academic Research in Business and Social Sciences, 11(3), 465-471.

\section{Copyright: (c) 2021 The Author(s)}

Published by Human Resource Management Academic Research Society (www.hrmars.com)

This article is published under the Creative Commons Attribution (CC BY 4.0) license. Anyone may reproduce, distribute, translate and create derivative works of this article (for both commercial and non-commercial purposes), subject to full attribution to the original publication and authors. The full terms of this license may be seen

at: http://creativecommons.org/licences/by/4.0/legalcode

Vol. 11, No. 3, 2021, Pg. 465 - 471

Full Terms \& Conditions of access and use can be found at http://hrmars.com/index.php/pages/detail/publication-ethics 


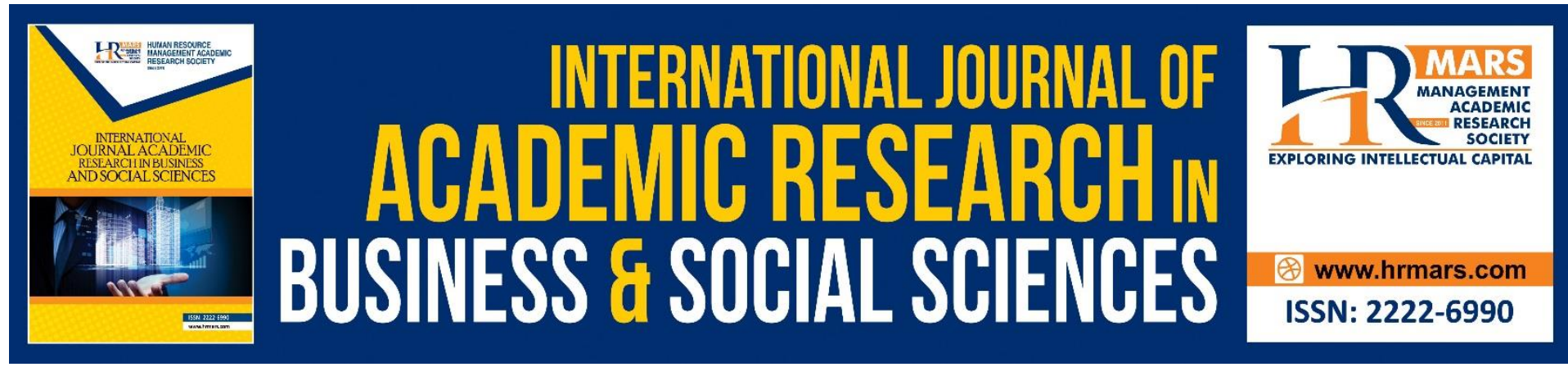

\title{
Exploring Factors Influencing Continuous Viewing Intention of Chinese Documentary Programs among Undergraduates
}

\author{
${ }^{1}$ Mengyu Li, ${ }^{2}$ Megat Al Imran Yasin, ${ }^{3}$ Norliana Binti Hashim, \\ ${ }^{4}$ Lay Hoon Ang, ${ }^{5}$ Hongzhe Kang \\ 1,2,3,5 Department of Communication, Universiti Putra Malaysia, Serdang, 43400, Selangor, \\ Malaysia, "${ }^{4}$ Department of Foreign Languages, Universiti Putra Malaysia, Serdang, 43400, \\ Selangor, Malaysia, ${ }^{1}$ School of Journalism and Communication, Zhengzhou University, \\ 45000, Zhengzhou, China \\ Email: megat@upm.edu.my
}

\begin{abstract}
This article used a qualitative method, using semi-structured interviews to select informants conduct online interviews with undergraduate students in mainland China to explore their continuous viewing intention as audiences towards Chinese documentary programs. Under the guidance of the theory of use and gratification, exploring the factors affecting continuous viewing intention which include cognitive needs, affective needs and tension free needs, and so on. Based on the different needs, they viewed Chinese documentary programs and when their satisfaction is very high, they are more inclined to continue viewing Chinese documentary programs. This study will do quantitative method to verify the UGT model to increase the reliability and validity of research results in the future.
\end{abstract}

Keywords: Undergraduate Students, Chinese Documentary Programs, Continuous Viewing Intention

\section{Introduction}

There are a lot of Chinese documentary programs that are widely accepted and recognized within Chine and even around the world. A documentary is described as a work of non-fiction that serves to express, capture, or document subjects that are rooted in reality. Nichols claimed that most of the documentaries become short yet crisp, giving out the exact message they want to (Nichols, 2017). Chinese documentary programs are also non-fiction films that mostly documents reality for keeping a historical record of past events. The purpose of those Chinese documentary movies is to instruct, educate, observe, and inform. New-biefilm school found some of the documentaries are also made in China just for education purposes (Newbiefilm school, 2019). Educational documentary programs are very popular among students in China. Most of the documentaries programs in China are made based on a true event, real facts, true historical trials which can enhance the subjective knowledge of the undergraduate students in mainland China. Reference shows many undergraduate students watch Chinese 
documentary programs to gain new knowledge about past historical events, movements, social reformation, etc (Berry \& Rofel, 2010). Several factors influence undergraduate students in mainland China to view Chinese documentary programs. Chinese documentary program is a useful resource for general audiences, students, professionals, researchers, and others who want to know the Chinese realistic events and Chinese society more deeply. It helps audiences to learn something new. These documentary programs are also effective and work as a learning tool for them who want to aware of some of the real facts about China and want to know the true historical story.

\section{Literature Review and Methods}

Before viewing Chinese documentary programs, undergraduate students in mainland China lookout for several issues. Firstly, they generally see who made it and whether there is any clear bias on the part of the researchers/producers/etc. They also see whether it seems to provide a comprehensive or full picture of the subject and is any information seemingly missing. And Liu believed they also observe do other sources contradict it; if so, which do they trust more (Liu, 2018).

Several factors influence undergraduate students in mainland China to continuously viewing Chinese documentary programs. The documentary programs are effective and work as a learning tool for them who want to familiar with some of the real facts about China and want to know the true historical story. These are considered as a useful resource for general audiences, students, professionals, researchers, and others who want to know the Chinese realistic events and Chinese society more deeply. Ma supposed it helps audiences to learn something new ( $\mathrm{Ma}, 2018)$. Underground maintained that it is observed that the main purpose of Chinese documentary programs is to highlight the reality of society and is usually about the topics that are intended for education and instruction purposes (Underground, 2019). So, it is very important to properly explore the needs that influence them. By taking into account this issue, the research objectives are: 1.To explore the needs as factors influencing viewing intention of Chinese documentary programs among undergraduates; 2 .To explore the reasons that undergraduates are interested to continuous view Chinese documentary programs.

Many undergraduate students in mainland China are a big fan of documentary and they thought documentary programs are so great that better than any other means of learning. It is found that many students save lots of documentaries that they thought are very useful and are hoping they could either memories a bit or at least find them when needed. These Chinese documentary programs are a source to show reality and maintain Chinese history. It is observed that the undergraduate students in mainland China watch documentary programs to enhance their knowledge about society, to improve their critical and creative thinking capacity, and to get some inspirational aspects from that. Further, Chinese documentary programs are used to teach principles in schools, colleges, and university students.

All documentary programs in China generally made these days include some of the real issues of society and educates the undergraduate students about it directly or indirectly. These programs are made entertaining so that the maximum students can get benefit from it as well as understand the topic too. It is perceived that undergraduate students in mainland China are very used to watch a lot of documentaries that exposed various historical knowledge, learning issues.

Actually, the qualitative approach will be through an interview with semi-structured question used to collect data from the subjects. It is essential to specify sample size earlier, or at the 
beginning of a qualitative study particularly in relation to interview or focus group studies. Predominantly, a number of researchers as debated on the best sample size in qualitative research within the social sciences. According to Hennink, Kaiser and Marconi claimed saturation is a fundamental regulatory standard towards determining sample sizes in qualitative research (Hennink, Kaiser \& Marconi, 2017). Reference illustrates that is the last interview in which a new code 'element' was identified or whereby there no new discoveries and information from the informants, which is within 7 and 25 (Anderson, Kelley \& Maxwell, 2017).Therefore, selecting sample size in the study is 15 .

\section{Results and Discussion \\ Undergraduates know the Realistic and True Event to Get the Satisfaction Via Chinese Documentary Programs}

Like other audiences of documentary programs, undergraduate students in mainland China find documentary programs as realistic programs and thus they prefer it over nondocumentary programs. The student feels more connected to a program when they realize it is based on a true event. Students can able to know everything related to that. Most important thing is that students can able to know both sides of the issue through documentary programs. Showing the facts as facts rather than fiction is a documentary program. Chinese documentary programs give the scope of the audience to know the real facts about anything. On the other hand, a documentary program is realistic. Documentary programs that are primarily documented for some degree of reality, are primarily directed or intended to present historical events. Movies often carry a metaphor for something in real life. This is a great way of communicating the problems in the world to the masses, but documentary can put audiences there almost first hand. Through Chinese documentary programs, undergraduate students can experience so many Chinese real stories in such a little amount of time. Above all, to know about some real facts undergraduate students of China get the motivation to watch Chinese documentary programs. This is another factor that encourages them to continue to view Chinese documentary.

\section{Students want to Continue Viewing the Chinese Documentary Programs to Enhance Knowledge}

Watching Chinese documentary programs have some positive effect on the students. They learn lots of new things from the programs and gain knowledge that otherwise may not gain. They can know and learn various types of moral habits with a moral story by watching those documentaries. Above all, they think it makes them smarter. Reference is shown that undergraduate students in mainland China get the motivation to watch Chinese documentary to gain knowledge that they may not be gained from other sources. From the curious mind, audiences especially students in mainland China want to gain some knowledge that they do not able to gain from any other sources (Chen, 2018). It is observed that there are some Chinese channels for the audiences/students where they can watch educational and historical documentary programs, those are based on real events. Undergraduate students' satisfaction is at a relatively high level mainly because they can gain subjective knowledge by viewing Chinese documentary programs. But in a nutshell, Kunze thought it can be said that getting knowledge about Chinese realistic \& true events, knowing both sides of any event, undergraduate students in mainland China continuing their view of watching documentary programs (Kunze, 2014). This is the cognitive needs that influence many undergraduate students in mainland China continuous viewing intention of Chinese documentary programs. 
Undergraduate students in China watch Chinese documentary programs continually as they think it may improve the critical and original thinking capacity. Evidences show that watching documentary helps students to enhance their thinking capacity. Feng fund students think this will help them to enhance their knowledge in their discipline (Feng, 2017). And watching a documentary can help a lot to enhance mainland Chinese student's critical and creative thinking. Watching Chinese documentary movies can expand the critical and creative thinking capacity of the students. The Socratic questioning method is important to live as it involves critical thinking of various subjects and mechanisms which are important in life. It involves indepth thinking, perseverance, and knowledge of various studied subjects in life.

\section{The Satisfaction of Undergraduates Stems from the Positive Emotions that can be Enhanced by Viewing Chinese Documentary Programs}

Documentaries can help to enhance family bonding. It is observed that in many families of China, parents, and other family members watch the Chinese documentary program together. Parents and educated family members and children who study in the university play a major role to watch documentaries in the family environment. As each family member has their own opinions and views about life thus different family member take Chinese documentary program from different perspectives. This culture enhances and strengthens the family bonding and create such a scope where the student finds learning materials there. This is the affective needs that influence many undergraduate students in mainland China towards continuous viewing intention of Chinese documentary programs.

Sometimes, undergraduate students in mainland China find an inspirational aspect in the documentary programs. There are lots of pieces of evidence that after watching documentary programs the life of the audiences has been changed. For instance, by watching the generous serving of humanities, the life of the audience can change a great extent. When students watch some brave deeds by anyone in that case they would be got inspiration and strive to match them. It is observed that there are several Insights into certain complex issues that may become clearer through watching documentary programs. Along with this, a documentary program can make students aware and motivate them to participate in a society actively. Above all, documentary programs can give undergraduate students new and positively influenced life.

\section{Fantastic Opportunity for The Student to Pass Time When Viewing Chinese Documentary Programs}

Many undergraduate students in mainland China think that watching Chinese documentary programs is a fantastic opportunity for them to pass time. This is one of the main factors (tension free needs) that influence them to continue to view Chinese documentary programs. It helps them to overcome many difficulties of time and space where it allows them to learn and build knowledge and skills without sacrificing their regular activities. It also allows them to gain lots of knowledge from various backgrounds and learn from different people. It also helps them to spend quality time when they do not have anything to do with other activities. So, passing leisure time effectively is a reason why undergraduate students continuing view Chinese documentary programs in mainland China.

Spreading awareness is another factor that influences the continuing view of Chinese documentary among undergraduate students of mainland China. They think that documentaries are an excellent means of spreading awareness among them via the visual medium. Documentaries are a masterly retelling of stories. They are credible accounts of the 
truths of life. No amount of creative recreations or seasoned actors can invoke the empathy, the bona fide first-hand chronicles of an actual person can. Authenticity is the essence of documentary programs. It compels the viewers to walk in the shoes of the subject, vicariously living their lives. So, to raise awareness among the people or to spread some important messages, students watch Chinese documentary programs.

\section{Conclusion}

Documentary programs in China are based on factual information and real events. Sometimes documentary programs are based on persons, places, and events that are also non-fictional. Many undergraduate students in mainland China are a big fan of documentary programs and they thought documentary programs are so great that better than any other means of learning. It is found that the undergraduate students in mainland China watch documentary programs to enhance their knowledge about society, to improve their critical and creative thinking capacity, and to get some inspirational aspects from that. Several needs (cognitive needs, affective needs, tension free needs) influence undergraduate students in mainland China to continuously viewing intention of Chinese documentary programs. Many undergraduate students in mainland China think that watching Chinese documentary programs is a fantastic opportunity for them to pass time. It is considered a learning tool around the world and China is not separated from that. They find documentary programs as realistic programs and thus they prefer it over non-documentary programs.

There is some significant contribution to undergraduate students activity for viewing Chinese documentary programs. By this way, Chinese documentary programs improve satisfaction and stimulate more audience to viewing them. So, it can be said that the contribution of Chinese documentary programs is based on the UGT model adds value to the audience by offering knowledge, positive emotions, tension free and entertainment. It is found that respondents said that virtually they can know well of the real society and events. The purpose of viewing Chinese documentary program is to help themselves. As a result, in a nutshell, it can be said that the needs influence undergraduates to view Chinese documentary programs. Specifically, cognitive needs, affective needs and tension free needs play a very significant role of continuous viewing intention of Chinese documentary programs.

\section{Acknowledgements}

This work was financially supported by Overseas Virtual Research Institute of Zhengzhou University and Associate Professor Jinglei Li (working in School of Journalism and Communication, Zhengzhou University).

\section{References}

Nichols, B. (2017). Introduction to documentary. Indiana University Press, Bloomington.

New-biefilm School. (2019). What is the Purpose of a Documentary? Newbie Film School. Online available from https://newbiefilmschool.com/what-is-the-purpose-of-adocumentary/

Berry, C. L. X. Y., \& Rofel, L. (2010). The new Chinese documentary film movement: For the public record. Hong Kong University Press, Hong Kong.

Liu, P. (2018). "OPPORTUNITY OR ADVERSITY?" CHINESE INTERNATIONAL STUDENTS AND ACTIVISM IN CHINA (PhD Thesis), Boston: Brandeis University.

MA, L. S. (2018). An Analysis of Chinese Documentary in We-media Times (Master Thesis), Bangkok University. 
Underground, C. (2019). 15+ essential documentaries to watch to understand China, ChinaUnderground Movie Database, Online available from https://chinaunderground.com/wp/2019/10/30/15-essential-documentaries-to-watch-tounderstand-china/

Hennink, M. M., Kaiser, B. N., \& Marconi, V. C. (2017). Code Saturation Versus Meaning Saturation: How Many Interviews Are Enough ? Qualitative Health Research, 27(04), 591-608.

Anderson, S. F., Kelley, K., \& Maxwell, S. E. (2017). Sample-Size Planning for More Accurate Statistical Power: A Method Adjusting Sample Effect Sizes for Publication Bias and Uncertainty, Psychological Science, 28(11), 1547-1562.

Chen, Z. W. (2018). Study on the Application of Film and Television Education in Cultivation of College Students' Values, Educational Sciences: Theory \& Practice, 18(05), 2419-2429.

Kunze, R. (2014). Tasting a Good Life: Narratives and Counter-Narratives of Happiness in the Documentary A Bite of China 2, China Perspectives, 2018(1-2), 45-53.

Feng, G. C. (2017). The dynamics of the Chinese film industry: Factors affecting Chinese audiences' intentions to see movies, Asia Pacific Business Review, 23(05), 658-676. 